\title{
Cancer incidence and cancer mortality in a cohort of semiconductor workers: an update
}

\author{
T Sorahan, D J Pope, M J McKiernan
}

In 1985 a report was published on incidence of cancer and cancer mortality among a cohort of 1807 workers from a semiconductor factory. ${ }^{1}$ For the total study cohort, observed numbers of deaths (and incident cases) for all cancers were close to those expected. For incidence of melanoma, three cases were observed and 0.68 were expected. This excess was of borderline significance at the $5 \%$ level and was not associated with either duration of employment in the plant or duration of employment in the photomasking process-a process that involves potential exposure to ultraviolet light. This report provides results from a further seven years of follow upnamely mortality data to the end of 1989 and data on the incidence of cancer to the end of 1988 .

\section{Materials and methods}

The study cohort has been described before. ${ }^{1}$ By the closing date of the study (31 December, 1989) the National Health Service Central Register (NHSCR) of the Office of Population, Censuses, and Surveys (OPCS) had traced 107 subjects who had died, 11 who had emigrated, and 1636 survivors. The 53 subjects who were untraced at the NHSCR were traced by other means. Thirteen of these were on the current electoral register, one was still employed with the company, and 39 were traced alive on 31 March, 1982 by the central offices of the Department of Social Security (DSS). Copies of death certificates were supplied by the NHSCR for the 107 employees known to have died, with the underlying cause of death classified according to the 8th revision of the International Classification of Diseases (ICD).

The OPCS also supplied details of cancer registrations from the National Cancer Registration Scheme. A computer search of the main index files of the West Midlands Regional Cancer Registry (WMRCR)

\begin{tabular}{|c|c|c|c|}
\hline $\begin{array}{l}\text { Department of Public H } \\
\text { University of } \\
\text { Birmingham B15 2TJ, UK }\end{array}$ & $\begin{array}{l}\text { lth and } \\
\text { ngham, }\end{array}$ & Epid & $\begin{array}{l}\text { niology, } \\
\text { baston, }\end{array}$ \\
\hline $\begin{array}{l}\text { T Sorahan, D J Pope } \\
\text { Lucas Industries plc, } \\
\text { Birmingham B19 2XF } \\
\text { M J McKiernan }\end{array}$ & Great & King & Street, \\
\hline
\end{tabular}

provided a further source of cancer registration data.

Expectations for mortality and incidence of cancer were calculated as described before. ${ }^{1}$

\section{Results}

Table 1 shows the observed and expected numbers of deaths from principal causes. Compared with the general population of England and Wales, this cohort experienced very low overall mortality (standardised mortality ratio $(S M R)=72$ ). In particular, low levels of mortality were found for cancer of the breast (SMR = 54), cancers of the genitourinary system $($ SMR $=21)$, diseases of the circulatory system $(S M R=70)$, and a remainder category $(S M R=38)$. Findings for skin cancer were close to expectation (expected $(E)=0.8 ;$ observed $(O)=1)$. No significant excess was found for any site of cancer (individual three digit ICD categories).

The deficit for mortality from all causes in the total study population is likely to be due, at least in part, to selection effects-namely, the "healthy worker effect" and the "survivor population effect". Evidence exists for a healthy worker effect in the census population (759 employees in employment on 1 January, 1970) with SMRs increasing with duration from first employment $(0-9$ years, $O=7, S M R=47 ; 10-19$ years, $O=25, S M R=60 ; \geqslant 20$ years, $O=41$, SMR $=108$ ). This effect was not seen in the entry cohort (1048 employees first employed in the period 1970-9) $(0-9$ years, $O=19, S M R=76 ; 10-19$ years, $O=15$, $S M R=51$ ).

Table 2 shows the observed and expected numbers of cancer registrations for the total study population. For all employees, the observed number was close to expectation (standardised registration ratio $(S R R)=$ 96). The deficit for women $(S R R=87)$ and the excess for men ( $S R R=140)$ are not statistically significant. The excesses shown for cancers of the skin (SRR = 159), reticuloendothelial neoplasms $(S R R=179)$, and the remainder category $(S R R=158)$ are also not statistically significant.

The findings for skin cancers relate to melanoma and other skin cancers. For melanoma, there were three cases compared with 1.50 expected. This difference is not statistically significant. Subtracting 
Table 1 Expected (E) and observed (O) deaths 1970-89, total study population

\begin{tabular}{|c|c|c|c|c|c|c|c|c|c|c|}
\hline \multirow[b]{2}{*}{ Cause of death } & \multirow{2}{*}{$\begin{array}{l}\text { ICD 8th } \\
\text { revision }\end{array}$} & \multicolumn{3}{|l|}{ Men } & \multicolumn{3}{|c|}{ Women } & \multicolumn{3}{|c|}{ Total } \\
\hline & & $E$ & $O$ & $(S M R)$ & $\boldsymbol{E}$ & $O$ & $(S M R)$ & $E$ & $O$ & (SMR) \\
\hline $\begin{array}{l}\text { Cancers of the: } \\
\text { Buccal cavity and throat } \\
\text { Digestive system } \\
\text { Respiratory system } \\
\text { Skin } \\
\text { Breast } \\
\text { Genitourinary system } \\
\text { Reticuloendothelial system } \\
\text { Other cancers } \\
\text { All cancers }\end{array}$ & $\begin{array}{l}140-149 \\
150-159 \\
160-163 \\
172-173 \\
174 \\
180-189 \\
200-207 \\
\text { Rem } 140-209 \\
140-209\end{array}$ & $\begin{array}{r}0 \cdot 2 \\
3 \cdot 6 \\
5 \cdot 0 \\
0 \cdot 1 \\
0 \cdot 0 \\
1 \cdot 4 \\
0 \cdot 8 \\
1 \cdot 3 \\
12 \cdot 4\end{array}$ & $\begin{array}{r}1 \\
4 \\
6 \\
0 \\
0 \\
0 \\
2 \\
3 \\
16\end{array}$ & $\begin{array}{r}(526) \\
(111) \\
(121) \\
(0) \\
(0) \\
(0) \\
(250) \\
(231) \\
(129)\end{array}$ & $\begin{array}{r}0 \cdot 4 \\
9 \cdot 2 \\
6 \cdot 9 \\
0 \cdot 6 \\
12 \cdot 9 \\
8 \cdot 3 \\
2 \cdot 6 \\
5 \cdot 0 \\
45 \cdot 9\end{array}$ & $\begin{array}{l}0 \\
7 \\
6 \\
1 \\
7 \\
2(\star) \\
2 \\
5 \\
30\left(^{\star}\right)\end{array}$ & $\begin{array}{r}(0) \\
(76) \\
(87) \\
(155) \\
(54) \\
(24) \\
(78) \\
(100) \\
(65)\end{array}$ & $\begin{array}{r}0 \cdot 6 \\
12 \cdot 8 \\
11 \cdot 9 \\
0 \cdot 8 \\
12 \cdot 9 \\
9 \cdot 7 \\
3 \cdot 4 \\
6 \cdot 2 \\
58 \cdot 3\end{array}$ & $\begin{array}{l}1 \\
11 \\
12 \\
1 \\
7 \\
2(\star \star) \\
4 \\
8 \\
46\end{array}$ & $\begin{array}{r}(159) \\
(86) \\
(101) \\
(130) \\
(54) \\
(21) \\
(118) \\
(129) \\
(79)\end{array}$ \\
\hline $\begin{array}{l}\text { Diseases of the: } \\
\text { Circulatory system } \\
\text { Respiratory system } \\
\text { Digestive system } \\
\text { Genitourinary system } \\
\text { Accidents } \\
\text { Suicide } \\
\text { All other causes }\end{array}$ & $\begin{array}{l}390-458 \\
460-519 \\
520-577 \\
580-629 \\
800-949 \\
950-959\end{array}$ & $\begin{array}{r}21 \cdot 3 \\
4 \cdot 3 \\
1 \cdot 1 \\
0 \cdot 4 \\
1 \cdot 3 \\
0 \cdot 7 \\
2 \cdot 3\end{array}$ & $\begin{array}{r}15 \\
3 \\
4 \\
0 \\
0 \\
0 \\
0\end{array}$ & $\begin{array}{r}(70) \\
(70) \\
(352) \\
(0) \\
(0) \\
(0) \\
(0)\end{array}$ & $\begin{array}{r}34 \cdot 0 \\
7 \cdot 1 \\
3 \cdot 6 \\
1 \cdot 2 \\
2 \cdot 7 \\
2 \cdot 0 \\
8 \cdot 2\end{array}$ & $\begin{array}{r}24 \\
3 \\
3 \\
2 \\
2 \\
1 \\
4\end{array}$ & $\begin{array}{r}(71) \\
(42) \\
(84) \\
(166) \\
(75) \\
(49) \\
(49)\end{array}$ & $\begin{array}{r}55.3 \\
11.4 \\
4.7 \\
1.6 \\
4.0 \\
2.7 \\
10.5\end{array}$ & $\begin{array}{l}39\left(^{\star}\right) \\
6 \\
7 \\
2 \\
2 \\
1 \\
4\left({ }^{\star}\right)\end{array}$ & $\begin{array}{r}(70) \\
(53) \\
(149) \\
(123) \\
(51) \\
(37) \\
(38)\end{array}$ \\
\hline All causes & & $43 \cdot 8$ & 38 & $(87)$ & $104 \cdot 7$ & $69(\star \star \star)$ & $(66)$ & $148 \cdot 5$ & $107(\star \star \star)$ & $(72)$ \\
\hline
\end{tabular}

${ }^{\star} \mathrm{p}<0.05 ;{ }^{\star \star} \mathrm{p}<0.01 ;{ }^{\star \star \star} \mathrm{p}<0.001 ;()$ indicates deficit.

Table 2 Incidence of cancer 1970-88, total study population

\begin{tabular}{|c|c|c|c|c|c|c|c|c|c|c|}
\hline \multirow[b]{2}{*}{ Site of Cancer } & \multirow{2}{*}{$\underset{\text { revision }}{\text { ICD }}$} & \multicolumn{3}{|l|}{ Men } & \multicolumn{3}{|c|}{ Women } & \multicolumn{3}{|l|}{ Total } \\
\hline & & $E \dagger$ & $O$ & $(S R R)$ & $E \dagger$ & $O$ & (SRR) & $E \dagger$ & $O$ & (SRR) \\
\hline $\begin{array}{l}\text { Buccal cavity and throat } \\
\text { Digestive system } \\
\text { Respiratory system } \\
\text { Skin } \\
\text { Breast } \\
\text { Genitourinary system } \\
\text { Reticuloendothelial system } \\
\text { Other cancers }\end{array}$ & $\begin{array}{l}140-149 \\
150-158 \\
160-163 \\
172-173 \\
174 \\
180-189 \\
200-207 \\
\text { Rem } 140-209\end{array}$ & $\begin{array}{l}0.4 \\
4.4 \\
5 \cdot 4 \\
2 \cdot 1 \\
0.0 \\
2 \cdot 6 \\
0.9 \\
1.4\end{array}$ & $\begin{array}{l}1 \\
7 \\
6 \\
2 \\
0 \\
0 \\
3 \\
5^{\star}\end{array}$ & $\begin{array}{r}(286) \\
(159) \\
(111) \\
(95) \\
(0) \\
(0) \\
(323) \\
(357)\end{array}$ & $\begin{array}{r}1 \cdot 0 \\
12 \cdot 3 \\
5 \cdot 9 \\
8 \cdot 0 \\
25 \cdot 9 \\
17 \cdot 4 \\
2 \cdot 9 \\
6 \cdot 3\end{array}$ & $\begin{array}{l}0 \\
10 \\
5 \\
14 \\
20 \\
9\left({ }^{\star}\right) \\
4 \\
7\end{array}$ & $\begin{array}{r}(0) \\
(81) \\
(85) \\
(176) \\
(77) \\
(52) \\
(136) \\
(111)\end{array}$ & $\begin{array}{r}1 \cdot 3 \\
16 \cdot 7 \\
11 \cdot 3 \\
10 \cdot 1 \\
26 \cdot 0 \\
20 \cdot 0 \\
3 \cdot 9 \\
7 \cdot 6\end{array}$ & $\begin{array}{l}1 \\
17 \\
11 \\
16 \\
20 \\
9(\star \star) \\
7 \\
12\end{array}$ & $\begin{array}{r}(78) \\
(102) \\
(97) \\
(159) \\
(77) \\
(45) \\
(179) \\
(158)\end{array}$ \\
\hline All cancers & $140-209$ & $17 \cdot 2$ & 24 & $(140)$ & $79 \cdot 7$ & 69 & (87) & 96.9 & 93 & (96) \\
\hline
\end{tabular}

${ }^{\star} \mathrm{p}<0.05 ; \star \star \mathrm{p}<0.01 ;()$ indicates deficit.

+ Expectations for the period $1970-7$ calculated from incidence rates in cancer incidence in five continents volume $I V^{2}$ and expectations for the period 1978-88 calculated from incidence rates in cancer incidence in five continents volume $V .^{3}$

these results from those reported in the previous paper ${ }^{1}$ the new information on incidence of melanoma $(1982-8)$ is zero cases found compared with 0.82 expected. Thus no new evidence exists for any excess risk of melanoma in this study population. For skin cancers other than melanoma, 13 cases were observed compared with 8.58 expected. This difference is not statistically significant. Only one of these cases had a histology of squamous cell carcinoma. New information on the incidence of these cancers-obtained in the same manner-comprised eight observed cancers and 4.65 expected. This difference is also not statistically significant.

Analyses for cancer registrations were also carried out for all individual sites of cancer (three digit ICD categories). No statistically significant excesses were found.

\section{Discussion}

The follow up of this cohort is still at an early stage, because among the entry cohort no subject has been followed up for more than 20 years from first employment. Nevertheless, the new information for incidence of melanoma is reassuring, and the likelihood that an occupational factor has increased the risk of melanoma among this cohort is much reduced. We are not aware of other cohort studies relating to a similar group of workers.

We thank the OPCS for flagging the study population, Sue Wilson for record linkage at the West Midlands Regional Cancer Registry, and Drs J A H Waterhouse and R H R Aston for their earlier participation in the study.

1 Sorahan T, Waterhouse JAH, McKiernan MJ, Aston RHR. Cancer incidence and cancer mortality in a cohort of semiconductor workers. Br J Ind Med 1985;42:546-50.

2 Waterhouse JAH, Muir C, Shanmugaratnam K, Powell J, eds. Cancer incidence in five continents. Vol 4. Lyon: International Agency for Research on Cancer, 1982. (IARC sci publ No 42.)

3 Muir C, Waterhouse JAH, Mack T, Powell J, Whelan S, eds. Cancer incidence in five continents. Vol 5. Lyon: International Agency for Research on Cancer, 1987. (IARC sci publ No 88.)

Accepted 8 July 1991 